Metals, 22 (1919), 67.

4) R. J. Anderson \& E. G. Fahlmen: J.Inst. Metals, 32 (1924), 367.

5) H. W. Swift: Proc. Inst. Automobile Eng., 39 (1940), 390.

6) N. Pairdenkow: Z. Metallk., 24 (1932), 25.

7) G. Sachs \& G. Aspey: Trans. A.I.M.E;, 147 (1942), 348.

8) D. Rosenthal \& J. T. Norton: Am. Welding Soc. Research Sup., May (1945), $295 \mathrm{~s}$ $\sim 307 \mathrm{~s}$.

9) 三橋鉄太郎, 上野 学: 本誌, 39, No.7 (1953) 722 .

io) H. Hanemann: Metallurgia 32 (1945), 62.

1.1) B. S. Lement, B, L, Averbach \& M, Cohen: Trans. A.S.M., 46 (1954), 851.

1.2) Philip Stark \& B. S. Lement: Journal of Metals, Sep., (1954), 1074.

13) C. D. Cobbs: Lubrication Eng., 9(1953), 73.

軸受鋼の熱処理による変形についで

$$
\text { 足立 } \because \text { 彰**。森 田善 一 郎*** }
$$

\title{
THE DISTORTION OF BALL BEARING STEEL AFTER VARIOUS HEAT-TREATMENTS
}

\section{Akira Adachi Dr. Eng, and Zen-ichiro Morita}

Synopsis:

The distortion of the standard specimens; A and B type, made of ball-bearing steel was measured after various heat-treatments, such as conventional heat-treatment and-interrupted quenching the so-called martempering or marquenching, and subzero-treatment.

The most of distortions on quenching were due to the thermal stress during the rapid cooling. By martempering, the thermal strains were eliminated excepting the unavoidable strains directly caused by austenite-martensite transformation. The distortion produced on quenching was reduced by subsequent tempering but increased by subzero-treatment, and in $A$ type specimen whose shape was so complicated its tendency was less than in B type.

From these experimental results, it was indicated that hot-oil quenching and martempering were suitable for the heat-treatment of ball-bearing steel, and that the distortion after quenchtemper-subzero-treatment was generally less than that after quench-subzero-treatment-temper.

\section{I. 緒 言}

軸受鋼では一般に水焼入または油焼入を行つて後焼戾 を行う処理かなされているが，最近ではマルテンパー或 いはマルクエンチ等の処理が行われ，またそれらのサブ ゼロ処理を実用化されつつある.

普通鋼の焼入際のに生ずる歪の原因とななるものは熱応 カわよひ変態応力であるい．熱応力は焼入尉に材料の各 部に急激なる温度变化を生ずる結果その温度差から生ず るもので, 水焼入等の如き冷却速度の非常に速い場合に はてれによる歪が著しい，また変態応力はオーステナィ トーマルテンサイト変態てよつて生ずるもので材料の膨 脹を伴うがししかしてれも Ms 点附近の椧却速鹿によつ てその大きさは異る，従つて烧入による变形量を減少さ
せるにはとれ等の熱応力と变態応力を軽減する事が必 要である.

そこで我々は軸受鋼の熱処理およびサブゼロ処理によ る变形の傾向を知るために，軸受鋼 (SUJ-2) の2つの 標準型娬料によりそれらを研究した。

\section{II. 実 験 試 料}

実験試料としては軸受鋼（SUJ-2）を使用した：その 化学組成は Table 1 亿示す如くである.

この試料を完全焼鈍後所定の寸法に切削加エし，更に

* 昭和 30 年 4 月本会講演大会にて発表

** 大阪大学教授 工博

*** " 大学院学生工修 
Table 1. Chemical oomposition of specimens.

\begin{tabular}{|c|c|c|c|c|c|c|c|c|}
\hline SUJ-2 & C & $\$ \mathrm{Si}$. & $\mathrm{Mn}$ & $\cdots \mathrm{cr}$ & $\mathrm{Ni}$ & $\begin{array}{r}\mathrm{R} \\
-\end{array}$ & $\mathrm{S}$ & $\mathrm{Cu}$ \\
\hline 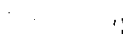 & $1: 03 \%$ & $0.23 \%$ & $0.37 \%$ & $1: 35 \%$ & $0,51 \%$ & $0.018 \%$ & $0.023 \%$ & $0.15 \%$ \\
\hline
\end{tabular}

低温焼鋌を行つた．武料の形状並びに寸㳙は Fig. 1に 示す如くである。

A-type
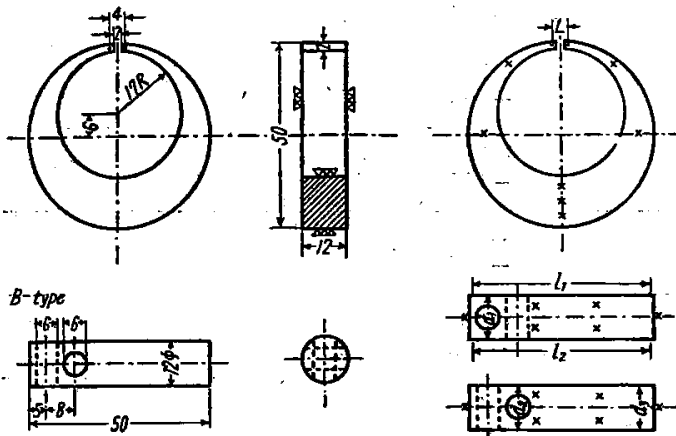

$L, 1_{1}, l_{2}, d_{1}, d_{2}, d_{3}:$ Distortion was measured $\times$ mark : Hardness was tested

Fig. 1. Size of specimen.

A型は複雑な形をしており尖端部と下部との肉厚の差 が大であり，B型は丸棒状で上部に互いに直角に穿つた

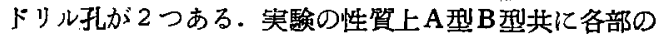
公差は $\pm 0.02 \mathrm{~mm}$ とし，全試料が同形同大になる様に した.

\section{III. 実 験 方 法}

上記試料を熱処理およびサブゼロ処理してその变形量

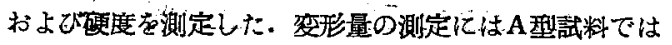
尖端部门標点を附し，この間隔を愤入前に正確に測定し てわき，烧入後,烓送後、サブゼロ边理後各々その間隔を 測定し焼入前との差を比較した．B型試料では直径方向

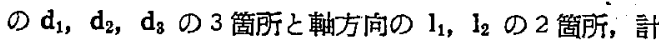
5 筒所を焼入前と焼入後, 焼戻後,サブゼ口処理後に測定 し，それらの $1 \mathrm{~cm}$ あたりの变形量を求めたＡ型およ びB型試料の福点打刻にはヴィツカース硬度計を用い夕 イヤモンド角錐にて附印し，また禋点距離は特別作製の 打刻售湍使用の下にA型では 400 $00.02 \mathrm{~mm}, \mathrm{~B}$ 型で は 48.00士0.02 mm とした.A 型およびB 型試料の軸 方向の变形量の測定には $1 / 100 \mathrm{~mm}$ 精度のコンパレー ターを，また B 型試料直径方向の变形量の測定には $1 /$ $1000 \mathrm{~mm}$ 精度のマイクロメーターを使用した。また硬度 の測定にはロックウェル硬淁しスケールを使用した。
試料の焼入加熱時の酸化わよひ脱㟶を防バために全て 真空加熱を行つた，焼入泠却郕としては水道水および市 販烧入油を使用した．試料の冷却槽への投入方向沈内部 応力の発生に影響し变形量を左右すると考えられるの で，A型試料では常に肉厚部より，B型試料ではドリル 孔の無い端より夫々液面に垂直に保つて投入した。

サブゼロ処理は烧入および烧入焼屄後 $30 \mathrm{mn}$ 以内に

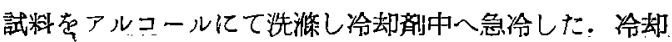

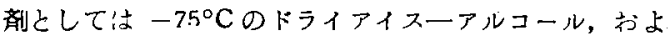
び $-195^{\circ} \mathrm{C}$ の液体等素を使用した。

なお本实験に使用した熱优理およびサブゼ口処理方法 は Table 2 に示す如くである。

\section{IV. 実験結果並びに考察}

\section{[1] 变形量}

一般に，烧入の際の変諺に主要なそして不可避的な影 变を与えるものは，比容積の増加即ち变態雨と焼入の際 の温度勾配による熱䅉である.熱歪は急冷の際, 熱応力か その温度における鋼の弾性限界上上に逆した時に発生す るちので，試料の表面に近い部分が中心部よりも速く冷 えて収縮を起すために内部は周用より王力を受ける事に なり，变形は体積に比輘して最も小さい表面積をとる傾

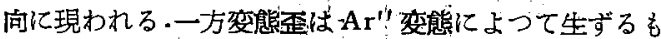
ので，との時には外周部がンテンサイトの生成により 膨脹するために中心部は 周囲より張力を受ける事にな り,熱歪上逆の方向に現われる.従つて焼入による变形は との2つの雪の総和とされている，征つて今A型陚料に ついて考えるならは断面樍の小さい部分は冷却速度まよ びマルテンサィト化の速度が速いために，その標点距離 は熱䇥においているけナス，変態歪ではプラスの方向に 進むと判断される.また $\mathrm{B}$ 型試料の如き円筒形のもので は，一般に㯖入の際の变形俚直径方向に賠脹し，軸方向 に収縮するのか通常とされている。

A型:

Fig. 2 はA型試料の焼大後の変形量を示す.

即ち水焼入の場合の变形量が最を大きく，次いで油㹸 入，温酒焼入，熱浴焼令の順になつている。珠に水烧入 の場合は武料による差が著しく，变形量が不規則であり 
Table 2. Heat-treatment and subzero-treatment.

\begin{tabular}{|c|c|c|c|c|c|c|c|c|}
\hline \multicolumn{3}{|c|}{ Quench } & \multicolumn{2}{|c|}{ Temper } & \multicolumn{2}{|c|}{ Subzero-treatment } & \multicolumn{2}{|c|}{ Temper } \\
\hline Treatment & $\begin{array}{l}\text { Heating } \\
\text { temp }{ }^{\circ} \mathrm{C}\end{array}$ & $\mid \begin{array}{c}\text { Heating } \\
\text { time mn }\end{array}$ & Temp & $\underset{\mathrm{mn}}{\text { Time }}$ & ${ }_{{ }^{\circ} \mathrm{C}}^{\text {Temp }}$ & $\underset{\mathrm{mn}}{\operatorname{Time}}$ & $\underset{\circ \mathrm{C}}{\text { Temp }}$ & $\underset{\text { mn }}{\text { Time }}$ \\
\hline \multirow{2}{*}{$\begin{array}{l}\text { Water-quench } \\
\left(11^{\circ} \mathrm{C}\right)\end{array}$} & \multirow{2}{*}{830} & \multirow{2}{*}{30} & 200 & 60 & $\begin{array}{l}-75 \\
-195\end{array}$ & $\begin{array}{l}60 \\
60\end{array}$ & \multicolumn{2}{|l|}{. } \\
\hline & & & $\therefore$ & & $\begin{array}{l}-75 \\
-195\end{array}$ & $\begin{array}{l}60 \\
60\end{array}$ & 200 & 60 \\
\hline \multirow{2}{*}{$\begin{array}{l}\text { Oil-quench } \\
\left(14^{\circ} \mathrm{C}\right)\end{array}$} & \multirow{2}{*}{830} & \multirow{2}{*}{30} & 200 & 60 & $\begin{array}{l}-75 \\
-195\end{array}$ & $\begin{array}{l}60 \\
60\end{array}$ & & \\
\hline & & & & & $\begin{array}{l}-75 \\
-195\end{array}$ & $\begin{array}{l}60 \\
60\end{array}$ & 200 & 60 \\
\hline \multirow{2}{*}{$\begin{array}{l}\text { Oil-quench } \\
\left(60^{\circ} \mathrm{C}\right)\end{array}$} & \multirow{2}{*}{830} & \multirow{2}{*}{30} & 200 & 60 & $\begin{array}{l}-75 \\
-195\end{array}$ & $\begin{array}{l}60 \\
60\end{array}$ & & \\
\hline & & & \multicolumn{2}{|l|}{$\cdot$} & $\begin{array}{l}-75 \\
-195\end{array}$ & $\begin{array}{l}60 \\
60\end{array}$ & 200 & 60 \\
\hline \multirow{2}{*}{$\begin{array}{c}\text { Martemper } \\
\left(200^{\circ} \mathrm{C} \times 3 \mathrm{mn}\right) \\
\text { air cool }\end{array}$} & \multirow{2}{*}{830} & \multirow{2}{*}{30} & 200 & 60 & $\begin{array}{l}-75 \\
-195\end{array}$ & $\begin{array}{l}60 \\
60\end{array}$ & \multicolumn{2}{|c|}{. } \\
\hline & & & & & $\begin{array}{l}-75 \\
-195 \\
\end{array}$ & $\begin{array}{l}60 \\
60\end{array}$ & 200 & 60 \\
\hline \multirow{2}{*}{$\begin{array}{c}\text { Martemper } \\
\left(200^{\circ} \mathrm{C} \times 5 \mathrm{mn}\right) \\
\text { air cool }\end{array}$} & \multirow{2}{*}{830} & \multirow{2}{*}{30} & 200 & 60 & $\begin{array}{l}-75 \\
-195 \\
\end{array}$ & $\begin{array}{l}60^{\circ} \\
60\end{array}$ & \\
\hline & & & & . & $\begin{array}{l}-75 \\
-195\end{array}$ & $\begin{array}{l}60 \\
60\end{array}$ & 200 & 60 \\
\hline
\end{tabular}

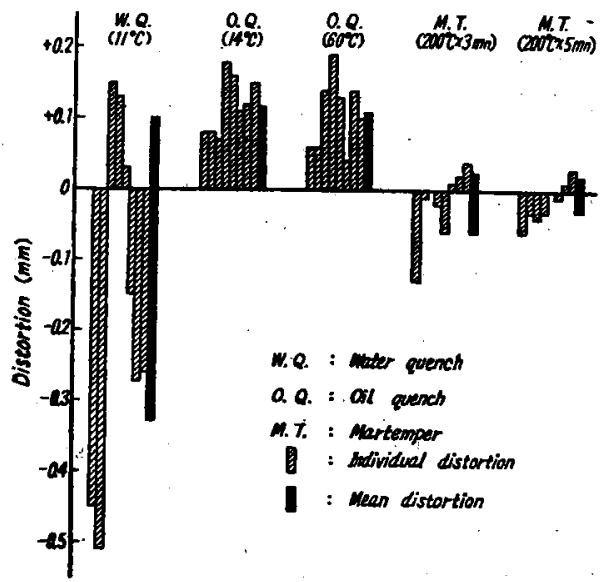

Fig. 2. Distortion of A-type specimens after quenching.

熱昰と变態垔の関係が不安定で变態の傾向き予測する事 は困難である：油焼入，温油焼入では变形量は何れもプ ラスに出ており，水焼入の埸合よりも小で試料による差

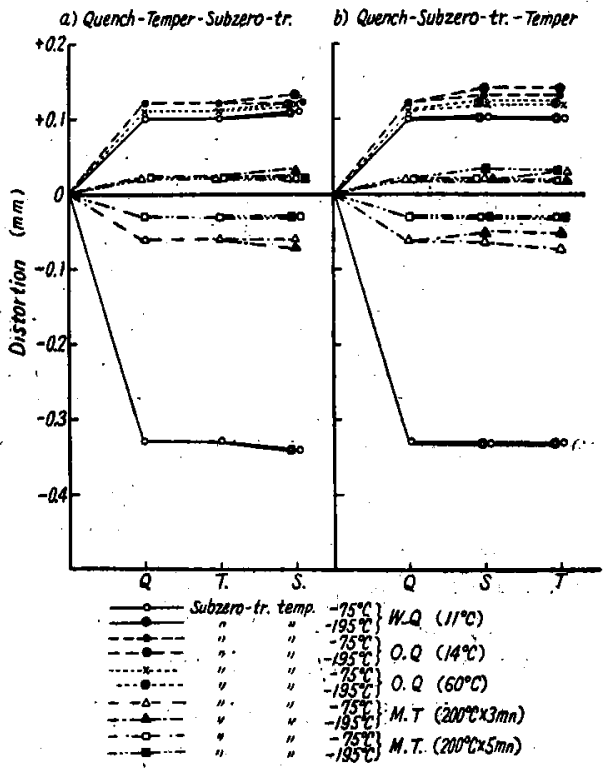

Fig. 3. Distortion of A-type specimens. 
る少い。即ちてれは水焼入代比して発生店力が少い事を

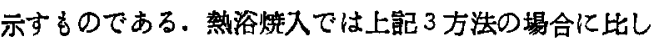

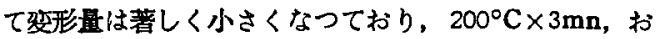
よび $200^{\circ} \mathrm{C} \times 5 \mathrm{mn}$ とでは後者の方がでく僅が小さい 結果を示している. 即ちてれ仿焼入の際 Ms 点附近を徐 命するために，上記 3 方法に比して熱店力および变態店 カが少い䊅果であろうと推察される。

Fig. 3 a) および b) はA型武料を夫々焼入一焼戻一 サブゼロ処理，焼入一サブゼロ处理一㛙戻を行つた埸合 の結果を示す。

Fig. 3a）では，何れの焼入方泆の揚合においても焼

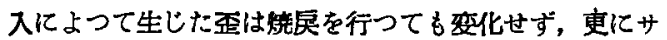
ブゼロ处理をすればでく僅加僧加の傾向を示しており それもサブゼロ処理温度の低い方即ち液体堊素で処理し た方が著しい. Fig. 3 b) では，各㮔焼入によつて生 ビた需は何れもサブゼロ処理によっててく僅かに增加の 颃向を示し，てれはまた更代房を行つても变化してい ない.Fig. 3 a) およぴ b) のサブゼロ处理による旡形 量の铛少なる增加は残留オーステナイトの分解によるも のと考えられる。

B型:

B型試料の各㮔熱逃理サブゼロ処理と变形量との関保 仙 Fig. 4 亿示す如くである. 同四 a) 㙂入一㜔戻一 サブゼロ処理，b）は焼入一サブゼロ処理一㜔㞍を行つ
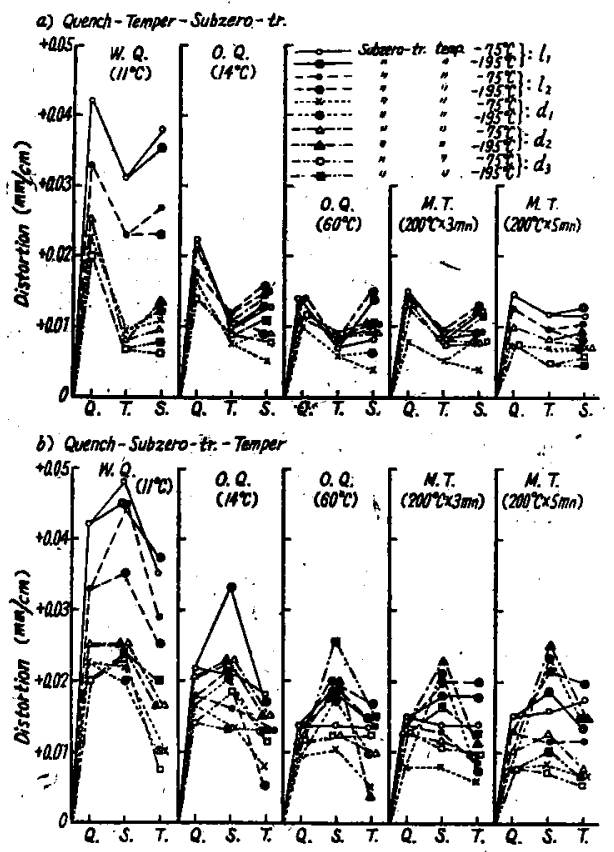

Fig. 4. Distortion of B-type specimens.
た場合の結果である。

B型試料においてもA型武糊の場合と同様焼入後の变

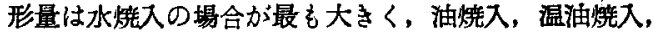
熱浴焼入の順になつておりり，温油焼入と $200^{\circ} \mathrm{C} \times 3 \mathrm{mn}$,

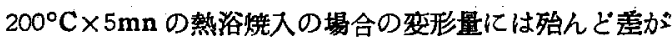
認められない：また一般に円筒形のちのでは，焼入の際の 雪は直径方向に膨脹し軸方向に収縮するのが普通とされ ているが，本B型武料では直径方向と其に軸方向にもま た瞦脹を示しており，しかもその变形量は直径方向にお けるものよりも大である。狫入一焼戻一サブゼ口处理を 行つたものでは Fig. 4 a) の如く焼入方法の如何を問 わす焼戾後の变形墨は減少しており，その嘒合は水㜔入 の場合において最も大きく，温油燒入，熱浴焼入にわいて 最も小さい。この㜔戾による变形量の減少は $\boldsymbol{\alpha}$-マルデ ンサイトー $\beta$ ーマルテンサイト努態汇よる収縮のためで

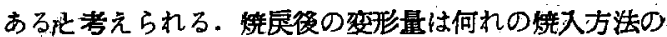
場合もよく似ており，温油焼入では軸方向直径方向の变 形量はほ保等しくなつている。とれ等を更にサブゼロ処 理すれば，变形量は再び增加する傾向を示すが丵入時程 著しくはない，また焼入一サブゼ口処理一焼戻を行つた ものではサブゼロ处理によって变形量は一样譜加して おり，処理温度の低い方がその增加の割合も大きい、この サブゼロ処理による形量の增加は残留オーステナイト の分解によるものと考えられる．更にてれを焼戻せば䘫

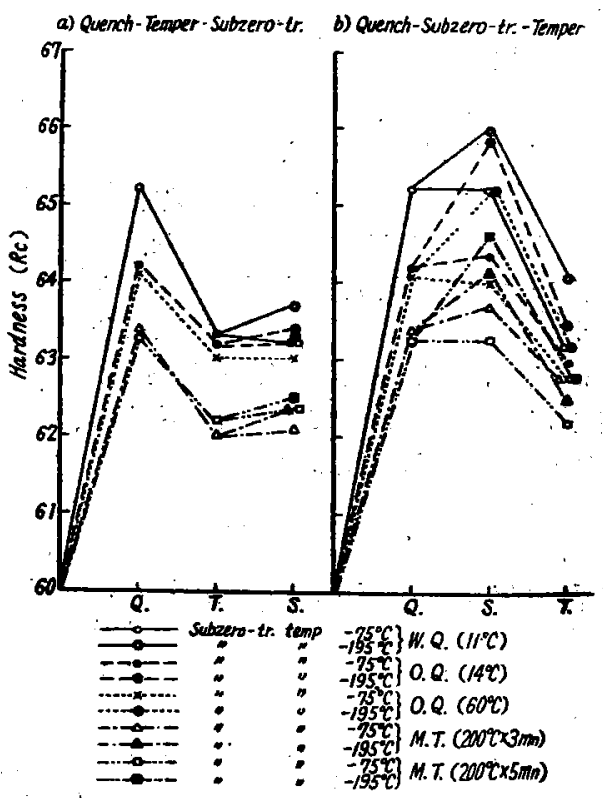

Fig. 5. Hardness of A-type specimens. 
形量は一様に減少しているが軸方向と直径方向による宦 が大きくなつている.

[2] 硬 度

Fig. 5 は A 型試料の各種熱処理並びにサブゼロ処理 による硬度の变化を示したるので，a）は焼入一焼戻一 サブゼロ処理やした場合，b）は焼入一サブゼロ処理一 焼杘ねした場合の結果である。

焼入後の硬度は水焼入にねいて最も高く，返に油焼入 が高く，温油焼入の場合の硬度は油焼入の場合と殆んど 变らない，熱浴焼入の場合の硬度は上記焼入の場合に比 して低く, $200^{\circ} \mathrm{C} \times 3 \mathrm{mn}$ と $200^{\circ} \mathrm{C} \times 5 \mathrm{mn}$ とではその差 は殆んど認められない.なわ゙武料による硬度のバラッキ は何れも最大 Rc 1 程度であり，油焼入と温油焼入では そのバラレキの程度が少い.

焼入一焼戻一サブゼロ処理における硬度の变化はFig： 5 a ) に示される如々, 焼扈後の硬度は水焼入では Rc 2,その他の焼A灰法では、Rc 1 程度低下している. こ れは焼㞔温度为高過ぎだ結果べーナイトが析出したため と思われる、またサブゼロ処理後の硬度はごく僅かに増 加の傾向を示しており, 処理温度 $-75^{\circ} \mathrm{C} と-195^{\circ} \mathrm{C}$ の場合『は後者の方为云の傾向ぶ大であり Rc で $1 / 2$ 程度何れる高くなつている.

また焼入一サブゼ口处理一焼戻における硬度の变化は Fig. 5 b) に示される如く焼大後の硬度はサブゼ口処 理によつて著しく増加し，その増加の割合も処理温度の 低い方が大である. この硬度の増加は勿論残留オーステ ナィトの分解によるものであり，てれはまた变形量が増 大している事からも納得でさる．焼戻後の硬度は何れも 非常に減少しており，熱浴焼入の場合は JIS による最 低硬度 Rc 63 以下になつている. 然し熱浴烧入直後の 硬度は何れも Rc 63 以上であるから，焼杘温度を低く する事によつて硬度の低下は防ぎ得ると考えられる。

Fig. 6 a) および b) は夫々B型武料を焼入一焼戻一 サブゼロ处理，焼入一サブゼロ処理一焼戻を行つた場合 の硬度の变化を示したものであるが，その变化の傾向は A型試料の場合と殆んど同じである.

\section{V. 総 括}

軸受鋼とて $\mathrm{A}$ 型およびB 型試料を作製し，各種熱処理 およびサブゼロ処理を行い，それらによる变形および硬 度について比較榆討したが，その結果を要約すれば次の 如くである。

（1）軸受鋼の焼入による变形量は水焼入において最 も大きく，次いで油焼入，温油焼入の順となつてわり，

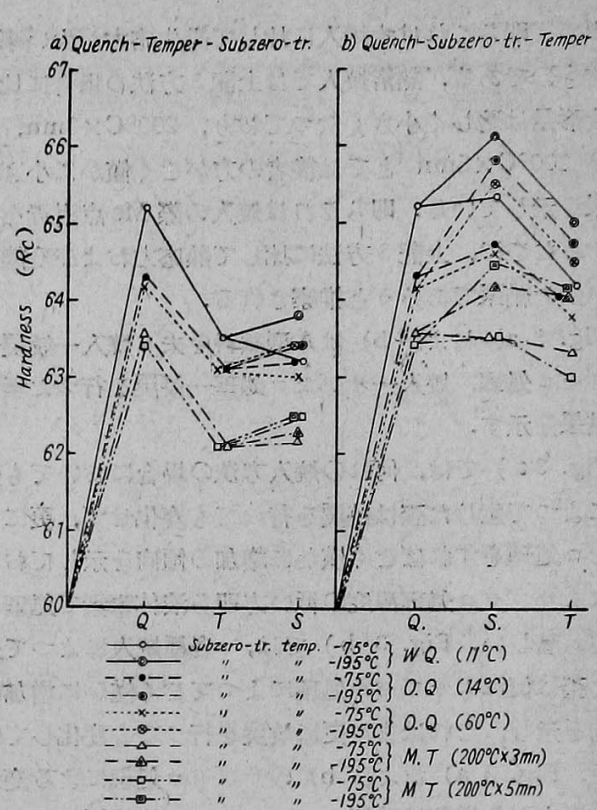

Fig. 6. Hardness of B-type specimens.

熱浴焼入において最も小さい，そしてA型試料の如きも のでは，焼入によつて一旦生じた雨は焼戾によつても变 化せず,サブゼロ処理によつてでく僅がに増加する・また B型試料の如きものでは，狫入によつて生じた歪は焼入 方法の如何を問わず烧戻によつて減少し，サブゼロ処理 によつて増加する.そしてサブゼロ処理温度の低い程増 加の割合が大きい.

（2）焼入後の硬度は水焼入において最も大きく，次 いで油焼入，温油焼入，熱浴焼入の順となつており，何れ の場合にもサブゼロ処理によつて硬度は増加する。また 焼入直後サブゼロ処理を行う場合と焼入焼杘後サブゼ口 処理を行う場合とでは，前者の万が増加の割合が大きく また処理温度の低い方がその効果も著しい，しかし乍ら $200^{\circ} \mathrm{C} \times 1 \mathrm{~h}$ の焼尼では何れの場合も硬度は減少し，焼 大時の硬度よりも低くなる。しかし燒屎温度を低くする 事によつて硬度の低下は防ぎ得る々考えられる。

（3）以上の結果より考えるならば，軸受鋼の焼入方 法としては温油焼入と熱浴焼入が最も適しており，また 焼入サブゼロ処理後焼戾するよりも焼入焼戻後サブゼロ 処理を行う方が变形量も小さく適当であると思われる.

(昭和 30 年 7 月寄稿)

文 献

1) J. Y. Riedel: Metal Progress (1950) Dec. 853 
2). H. J. French: Tr. ASST 12 (1930) 848

3) R, P. Seeling: Iron Age (1949) Sept. 72

4) H. Scott \& T. H. Gray: Tr. ASM. 29 (1941)

5) K. Rose: Material \& Method (1950) Nov. 66

6) L. H. Seabright: Iron Age 68 (1951) 101
7) J. P. Gill, G. A. Roberts, H. G, Johnstin, Burns George: Tool Steel (1946)

8) M. Cohen: Tr. ASM. 41 (1949) 35

9.)三橋鉦太郎, 上野学: 鉄之䠒 (1953) 722

10）定立彰，山时新太郎：铁之鍼（1954） 116

11）安田洋一，村治解明：鉄と䠒（1954） 1066

\title{
ガスタービン用 $\mathrm{Ni}-\mathrm{Cr}-\mathrm{Co}$ 系 (20-15-15\%) 耐熱鋼の 諸性貿におよばす $\mathrm{Nb}, \mathrm{V}, \mathrm{Ti}$ および $\mathrm{N}$ の影響*
}

小柴 定 雄**.九重 常 男***

\section{THE EFFECTS OF Nb, V, Ti AND N ON THE PROPERTIES OF Ni-Cr-Co} (20-15-15\%) SERIES HEAT-RESISTING STEEL FOR GAS TURBINES

\author{
Sadao Koshiba, Dr. Eng., Tsuneo Kuno
}

In the previous report, ("Hitachi Hyoron" No. 11, 1955) the authors described the effects of $\mathrm{Nb}, \mathrm{V}, \mathrm{Ti}$ and $\mathrm{N}$ on the properties of $\mathrm{Ni}-\mathrm{Cr}(20-15 \%)$ series heat-resisting steel for gas turbines. In this report, the authors examined the effects of $\mathrm{Nb}, \mathrm{V}, \mathrm{Ti}$ and $\mathrm{N}$ on the forgeability, solution-treatment, hardness, aging hardness, microstructure, mechanical properties at high temperature, oxidation resistance and creep limits of $\mathrm{Ni}-\mathrm{Cr}$-Co $(20-15-15 \%)$ series heatresisting steel for gas turbines.

The results obtained were summarized as follows:

1) In respect to forgeability, $\mathrm{Nb}$ was superior, while the specimen $\mathrm{A}$ (which contained no special element) $\mathrm{Ti}$ and $\mathrm{V}$ were comparatively good next to $\mathrm{Nb}$, and then $\mathrm{N}$ had worse effect on it.

2) When the solution temperature was $1200^{\circ} \mathrm{C}$, the specimen " $\mathrm{A}$ " showed highest aging hardness. Next to the specimen "A", those with N, V, Ti and Nb were good in the term.

3) $\mathbf{N}$ conferred the best property in the tensile strength at high temperature, however when the temperature rose above $700^{\circ} \mathrm{C}$, the differences between the properties pf steels with different elements became very small.

4) In respect to oxidation resistance, $\mathrm{Nb}$ was most effective and $\mathrm{V}$ had worse effect on it.

5) As for the creep limit, the specimen "A" was superior, and then, next to " $A$ " * specimens containing $\mathrm{Ti}, \mathrm{N}, \mathrm{V}$ and $\mathrm{Nb}$ were good in the term.

\section{I. 緒言}

日本鉄鋼協会第 49 回講演大会にて Ni-Cr 系耐熱鋼 の諸性慰におよばす Nb, V,Ti およびNの影響につか て報告した分は「日立評論了金属特集号（別冊 No. 11 . 1955 昭和 30年9月発行）に掦載したが，今回はCoを. 含む $\mathrm{Ni-Cr}-\mathrm{Co}$ 系 (20-15-15\%) 耐熱鍶におよはすす $\mathrm{Nb}$ V, : Ti およびNの影㸷について央験を行つた.

耐熱鐡に高温強度を附与するためにはCo が是非必要 である. 使用洞度 $800^{\circ} \mathrm{C}$ 上上の高温においては Co 45 \%を含む S .816 等が広く用いられている.かように多
量のCo を用いることは高温強度を増大せしめる反面，

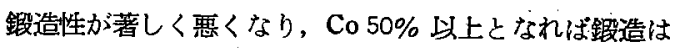
殆んど不可能となる．まだ資源の不足により極めて高価 となり，多量の使用は避けなければならない，加ような 意味において現在: Co 基耐熱鋼としては N-155（Ni， $\mathrm{Cr}, \mathrm{Co}$ 各 20\%) 禾統加広く使用されている：そこで筆 者等は更に.Co を節約するととを目的として，前述の特 殊元素の影響について実験を行つた。

* 昭和 30 年 4 月本会满演大会に誹演

*** 日立整作所安来工場冶金研究所 工博

*** 日立製作所安来工場话金研究所 